\title{
Histological and immunohistochemical evaluation in patients who underwent maxillary sinus lifting surgery using autogenous or heterogenous bone. A clinical randomised trial
}

\author{
Avaliação histológica e imunohistoquímica em pacientes submetidos à cirurgia de levantamento de \\ seio maxilar com osso autógeno ou heterogêneo. Um ensaio clínico randomizado
}

Evaluación histológica e inmunohistoquímica en pacientes sometidos a cirugía de elevación del seno maxilar con hueso autógeno o heterogéneo. Un ensayo clínico aleatorizado

Received: 03/22/2021 | Reviewed: 03/29/2021 |Accept: 04/08/2021 | Published: 04/1 8/2021

Geraldo Luiz Griza

ORCID: https://orcid.org/0000-0001-7169-495X Parana West State University, Brazil

E-mail: ggriza@hotmail.com

Roberta Okamoto

ORCID: https://orcid.org/0000-0002-6773-6966 Universidade Estadual Paulista, Brazil E-mail: roberta.okamoto@unesp.br

Daniela Colet

ORCID: https://orcid.og/0000-0001-7317-0762 Private dental Office, Brazil

E-mail: danicolet@hotmail.com

Ricardo Augusto Conci

ORCID: https://orcid.org/0000-0002-6678-8780 Parana West State University, Brazil E-mail: ricardo_conci@hotmail.com

Osvaldo Magro Filho

ORCID: https://orcid.org/0000-0002-9821-2479 Universidade Estadual Paulista, Brazil E-mail: osvaldomagrofilho@icloud.com

\begin{abstract}
Objectives: This study evaluated, through histological and immunohistochemical analysis the bone formation and remodeling after a maxillary sinus lift. Material and methods: 25 patients from 41 to 65 years of age, with inadequate bone volume in the posterior maxillary region and remaining native bone less than or equal to $5 \mathrm{~mm}$, as measured radiographically, were selected and underwent maxillary sinus lift surgery, through the open technique. They were distributed in 3 groups: A - particulate, autogenous bone, $\mathrm{AB}$ - autogenous and heterogeneous bone, and $\mathrm{B}$ - only heterogeneous bone. Six months after this intervention, the patients were submitted to a surgery for the installation of implants and concomitant removal of the grafted bone sample from the surgical site. Results: The histological evaluation showed bone formation in the three groups, with presence of mature bone. In groups $\mathrm{B}$ and $\mathrm{AB}$, the presence of granules of the biomaterial surrounded by bone tissue was observed. A statistical analysis showed significant difference (ANOVA $\mathrm{p}=0,002$ ), suggesting greater bone formation in the autogenous group. In an immunohistochemical evaluation, no statistically significant differences were observed in the comparison between the experimental groups (A, B and $\mathrm{AB}$ ), as well as in the proteins analyzed (OC: $\mathrm{p}=0.657$; VEGF: $\mathrm{p}=0,133$; TRAP: $\mathrm{p}=0.163$ ). Conclusion: The use of Bio-Oss ${ }^{\circledR}$, whether or not associated to autogenous bone, for a maxillary sinus lift through the side window technique results in bone repair. A predictable amount of bone formation is attained when this osteoconductive biomaterial is used.
\end{abstract}

Keywords: Biomaterials; Maxillary sinus; Graft bone.

\section{Resumo}

Objetivos: Este estudo avaliou, por meio de análises histológicas e imunohistoquímicas, a formação e remodelação óssea após a elevação do seio maxilar. Material e métodos: foram selecionados 25 pacientes de 41 a 65 anos de idade, com volume ósseo inadequado na região posterior da maxila e osso nativo remanescente menor ou igual a $5 \mathrm{~mm}$, medido radiograficamente, que foram submetidos à cirurgia de levantamento do seio maxilar, por meio da técnica aberta. Eles foram distribuídos em 3 grupos: A - osso particulado, autógeno, AB - osso autógeno e heterogêneo e B - somente osso heterogêneo. Seis meses após essa intervenção, os pacientes foram submetidos à cirurgia para instalação de implantes 
e concomitante retirada da amostra óssea enxertada do sítio cirúrgico. Resultados: A avaliação histológica evidenciou formação óssea nos três grupos, com presença de osso maduro. Nos grupos B e AB foi observada a presença de grânulos do biomaterial circundados por tecido ósseo. A análise estatística mostrou diferença significativa (ANOVA p = 0,002), sugerindo maior formação óssea no grupo autógeno. Na avaliação imunoistoquímica, não foram observadas diferenças estatisticamente significativas na comparação entre os grupos experimentais (A, B e AB), bem como nas proteínas analisadas (OC: $p=0,657$; VEGF: $p=0,133$; TRAP: $p=0,163$ ). Conclusão: O uso do Bio-Oss $®$, associado ou não a osso autógeno, para a elevação do seio maxilar pela técnica de janela lateral resulta em reparo ósseo. Uma quantidade previsível de formação óssea é atingida quando este biomaterial osteocondutor é usado.

Palavras-chave: Biomateriais; Seio maxilar; Enxerto ósseo.

\section{Resumen}

Objetivos: Este estudio evaluó, mediante análisis histológico e inmunohistoquímico, la formación y remodelación ósea después de una elevación del seno maxilar. Material y métodos: se seleccionaron 25 pacientes de 41 a 65 años, con volumen óseo inadecuado en la región maxilar posterior y resto de hueso nativo menor o igual a $5 \mathrm{~mm}$, medidos radiográficamente, y se les realizó cirugía de elevación del seno maxilar, a través de la técnica abierta. Se distribuyeron en 3 grupos: A - hueso particulado, autógeno, AB - hueso autógeno y heterogéneo, y B - solo hueso heterogéneo. Seis meses después de esta intervención, los pacientes fueron sometidos a una cirugía para la instalación de implantes y la extracción concomitante de la muestra de hueso injertado del sitio quirúrgico. Resultados: La evaluación histológica mostró formación ósea en los tres grupos, con presencia de hueso maduro. En los grupos B y AB se observó la presencia de gránulos del biomaterial rodeados de tejido óseo. Un análisis estadístico mostró diferencia significativa (ANOVA p = 0,002), sugiriendo una mayor formación ósea en el grupo autógeno. En una evaluación inmunohistoquímica no se observaron diferencias estadísticamente significativas en la comparación entre los grupos experimentales (A, B y AB), así como en las proteínas analizadas (OC: $\mathrm{p}=0,657$; VEGF: $\mathrm{p}=0,133$; TRAP: $\mathrm{p}=0,163$ ). Conclusión: El uso de BioOss ${ }^{\circledR}$, asociado o no a hueso autógeno, para una técnica de elevación del seno maxilar a través de la ventana lateral da como resultado la reparación ósea. Se logra una cantidad predecible de formación de hueso cuando se usa este biomaterial osteoconductor.

Palabras clave: Biomateriais, Seno maxilar; Osso de enxerto.

\section{Introduction}

The treatment of maxillary edentulous jaws with osseointegrated implants is often complex for the pneumatization of the maxillary sinus and for the remaining low-bone density and volume. The bone resorption, consequent to the loss of the dental elements, determines atrophy in height and thickness, by reducing the available bone to perform the implant (Stacchi et al., 2017; Beretta et al., 2012).

The maxillary sinus is a large pyramidal cavity with thin walls corresponding to alveolar, orbital, facial and infratemporal aspects of the maxilla. The size, shape, and wall thickness of the sinus varies from one to another even on the 2 sides of the pacient. Normally, the normal thickness of the Schneiderian membrane is approximately $1 \mathrm{~mm}$ (Rancitelli et al., 2015).

The maxillary sinus lift is a widely used technique to restore bone volume in the posterior region of the maxilla for dental implant placement (Jensen et al., 2012; Abrahams \& Hayt, 2000). The classic technique consists in a lateral access to the maxillary sinus, detachment of the Schneider membrane, and maintenance of the distance from the membrane to the sinus floor. Once this space is preserved, new bone is formed filling it over time (Tatum, 1986; Chiapasco, Casentini \& Zaniboni, 2009; Raja, 2009).

Maxillary sinus floor augmentation can be considered a relative safe procedure, but severe complications may occur as a result of incorrect surgical plan or related to aggressive surgical manoeuvres (Stacchi et al., 2017; Beretta et al., 2012; Rancitelli et al., 2015; Maridati et al., 2014).

There are many studies regarding anatomic variation of maxillary sinus, just a few of them are concerned with the relation between septa and Schneiderian membrane (Rancitelli et al., 2015).

The anatomic knowledge of maxillary sinus is fundamental to plan its surgical lift avoiding possible complications (Rancitelli et al., 2015). Some complications may arise during this procedure. The perforation of sinus membrane and interruption of the alveolar-antral vascular bundle are the two most frequent intra-operative complications. The alveolar antral artery is an 
anastomosis between the infraorbital artery and the posterior superior alveolar artery and it is really important due this surgical technique (Stacchi et al., 2017; Maridati et al., 2014).

The maintenance of the space created is crucial for the bone formation, and thus the insertion of autogenous bone or bone substitutes are commonly used not only for space preservation but also to afford the migration of osteoblasts and matrix deposition over the particles' surface (Schweikert, Lang \& Botticelli, 2011).

Autogenous bone represented for years the standard in bone reconstructions. The bone architecture combined with autologous bone morphogenic proteins (BMPs) and stem cells inside the woven structure provides unique characteristics for this material as it is osteoconductive, osteogenic and osteoinductor (Abrahams \& Hayt, 2000; Chiapasco, Casentini \& Zaniboni, 2009). Despite the optimal biological proprieties, the harvesting of autogenous bone implies a second surgical approach with consequent increase of morbidity and surgical time. Bone substitutes are commonly used in bone reconstruction surgeries in order to prevent the negative aspects of autogenous bone harvesting. There are a number of bone substitutes of different origins, heterogeneous bone being one of the most popular among them with proven efficacy in the bone formation of sinus lift surgeries (Abrahams \& Hayt, 2000; Stern \& Green, 2012).

The aim of this study was to emphasize the importance of this kind of procedure in oral and maxillofacial surgery due to the high number of patients who need this rehabilitation. Another goal of this study was to evaluate bone formation by histological and immunohistochemical analysis and characterize the events that mark the bone remodeling following a maxillary sinus lift surgery filled with three types of bone graft: particulate autogenous bone; autogenous and heterogeneous bone; only heterogeneous bone.

\section{Materials and Methods}

This study was approved by the Human Research Ethics Committee of the University of the State of São Paulo UNESP/ Araçatuba (05509112.4.0000.5420) where this protocol can be found. All the patients were well informed about the research and signed the written informed consent form.

A total of 74 dental implants were installed. Among these, 38 bone tissue samples of the patients were collected during the alveolar ridge perforation and subjected to histological and immunohistochemical processing for the detection of osteocalcin protein, vascular endothelial growth factor (VEGF) and tryptophan-activated RNA binding attenuation protein (TRAP) in the the analyzed bone tissue.

The scientific methodology followed several technical criteria, mainly supported by the author José Carlos Köche (2011).

\section{Patient Selection}

The number of the samples for each group was determined by a statistical power test (http://www.lee.dante.br) based on previous results (Bonardi et al., 2017). The selection of patients is shown in the CONSORT flow diagram (Figure 1). 
Figure 1 - The CONSORT flow diagram.

\section{CONSORT 2010 Flow Diagram}

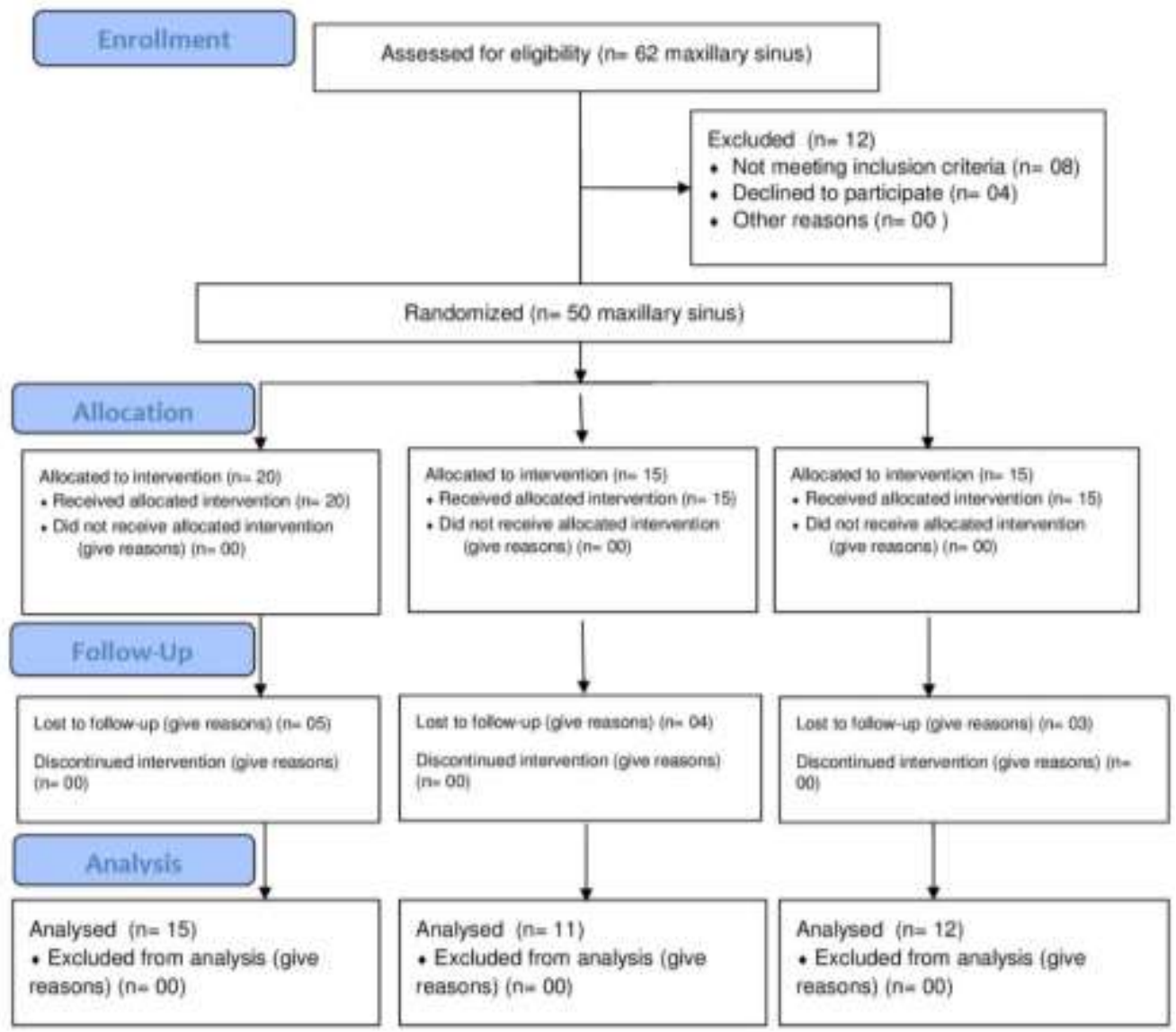

Source: Authors.

The patient inclusion criteria for this study were:

- Systemic analysis: ASA class I and II surgical risk; absence of respiratory diseases.

- Orçlal conditions: Indication for rehabilitation with dental implant; panoramic radiography showing insufficient alveolar bone to place the dental implants; and the presence of a maxillary sinus occupying the space where the dental implant should be positioned.

Thirty-eight (38) maxillary sinus lifts were performed in 25 patients of both genders, aged between 41-65 years (Table 1), with inadequate bone volume in the posterior maxillary region and remaining native bone less than or equal to $5 \mathrm{~mm}$, measured radiographically, and selected to perform a bone reconstructive surgery for subsequent installation of implantsupported prostheses. 
Table 1 - Distribution of patients according gender and age.

\begin{tabular}{cccc}
\hline Total of patients & Gender & Age & Avarage Age \\
\hline 25 & Males - 13 & $41-65$ & $51 \pm 7$ \\
\cline { 2 - 3 } & Females - 12 & & \\
\hline
\end{tabular}

\section{Source: Authors.}

Diagnostic imaging of the maxillary areas and donor sites (chin and mandibular branch) was performed for the selection of patients, the selected harvesting site being in the highest volume area.

Exclusion criteria were patients with uncontrolled systemic problems, smoking, a history of radiation in the head and neck areas, periodontal disease, or sinus conditions.

\section{Bone Graft surgeries}

The patients underwent a surgery to elevate the maxillary sinus through the side window technique recommended by Tatum $^{3}$ and divided into 3 groups according to the type of graft used: Group A - particulate autogenous bone; Group AB autogenous and heterogenous bone (Bio-Oss ${ }^{\circledR}$ ), and Group B- only heterogenous bone (Bio-Oss ${ }^{\circledR}$ ), according to the type of filling of the maxillary sinus (Table 2).

Table 2 - Groups distibrution.

\begin{tabular}{ccc}
\hline Groups & Bone substitutes & Number of sinus \\
\hline A & Autogenous bone & 15 \\
\hline AB & $1: 1$ Bio-Oss $®($ Geistlish AG)+ autogenous bone & 11 \\
\hline B & BioOss $®($ Geistlish $A G)$ & 12 \\
\hline
\end{tabular}

Source: Authors.

The patients were allocated to the groups by simple randomization. Before each surgery, the technique to be performed was drawn by lots. This process was generated by the main author, who also enrolled the patients and assigned them their interventions.

The intrabucal donor areas of the bone graft were chosen by the researcher according to the amount or volume of bone required for the grafted site (chin or mandibular ramus).

For particulate autogenous bone, a manual bone grinder was used (Neodent - Brazil). For group B, the proportion was approximately $50 \%$ of each bone type (1: 1).

Patients were treated prophylactically with antibiotics and corticosteroids and, in the postoperative period, with analgesics and nonsteroidal anti-inflammatory drugs. They were anesthetized according to conventional regional block techniques and underwent surgery.

Before being discharged, the patients were given postoperative care instructions and, after two weeks, returned for evaluation, removal of the suture, and follow-up of the case.

\section{Sample acquisition}

Six (6) months after the graft procedure, the patients returned for a new surgical procedure aiming at the placement of osseointegrated dental implants. In this step, a sample of the grafted bone was extracted for biopsy with a 2-mm-diameter 
trephine-type drill (Neodent - Brazil) in the vertical direction (Figure 2), according to the planned position for the implantation of the implant: an external Hexagon (PI Brånemark® -Zimmer / Brazil), of diameter and length compatible with the need of each location. The patients were conventionally anesthetized and medicated in a similar manner to the grafting stage.

Figure 2 - Technique of the biopsy with trephine-type drill.

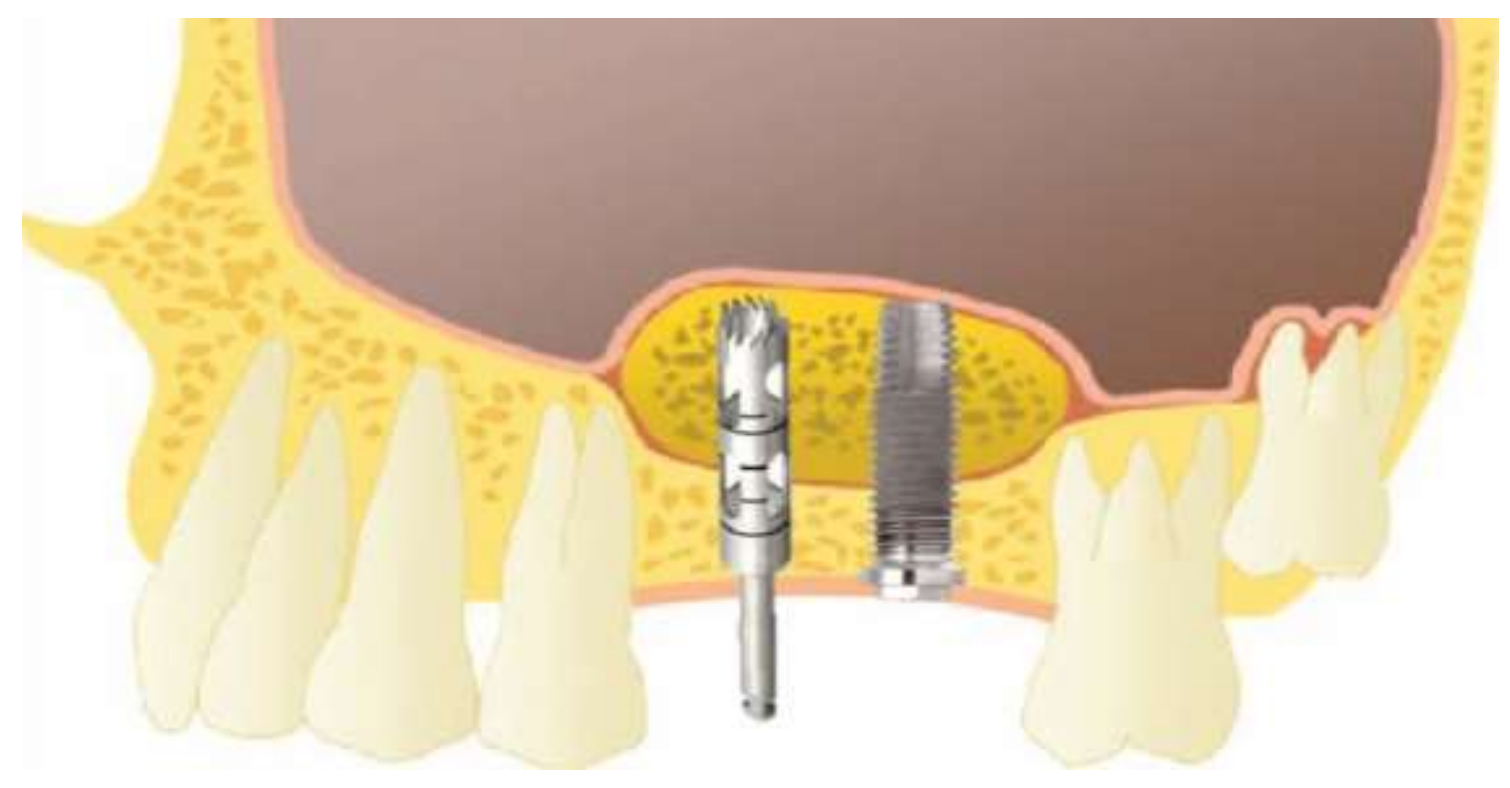

Source: Authors.

\section{Histological analysis}

The parts were processed in the Laboratory of the Department of Surgery and Integrated Clinics of FOA-UNESP.

The obtained pieces were fixed in a 10\% buffered formalin solution, $\mathrm{pH}=7$ for 48 hours, decalcified in 5\% EDTA (Ethylene Diamino-tetraacetic Acid - Merck-Frankfort / Germany) for 42 days, embedded in paraffin and submitted to microtomy to obtain $6 \mu \mathrm{m}$-thick longitudinal sections for histomorphometric and immunohistochemical analysis.

A conventional Carl Zeiss-Jenamed 2 light microscope (Jena / Germany) was used under a fixed focus and field clarity, with an initial increase of $63 \mathrm{X}$ and $400 \mathrm{X}$. At least four histological sections of each specimen were evaluated. A calibrated observer identified the tissue morphology of each group.

The images of the semi-serial sections of the specimens to evaluate the bone neoformation of the grafted area were captured by a digital camera (Axiocam ICc1- Zeiss-Jena / Germany) coupled to a Carl Zeiss-Jenamed 2 (Jena / Germany) optical microscope and connected to a Itautec infowayST43443329 DC computer, monitor LG E2355V, 800x600 dpi. The images were captured at $63 \mathrm{X}$ magnification just above the interface between the remaining bone, thus capturing the grafted area. The Image J digital image processing program was used to evaluate the photos. The same was calibrated in 8000 pixels, which allowed the count of 192 points in the total area of the image. The points present in the area of neoformed bone were counted, and it was verified that they were no areas of grafted bone. It was then transformed into area density (\%), considering the total area of 192 points as $100 \%$ (Figure 3). 
Figure 3 - Counting of the area of neoformed bone.
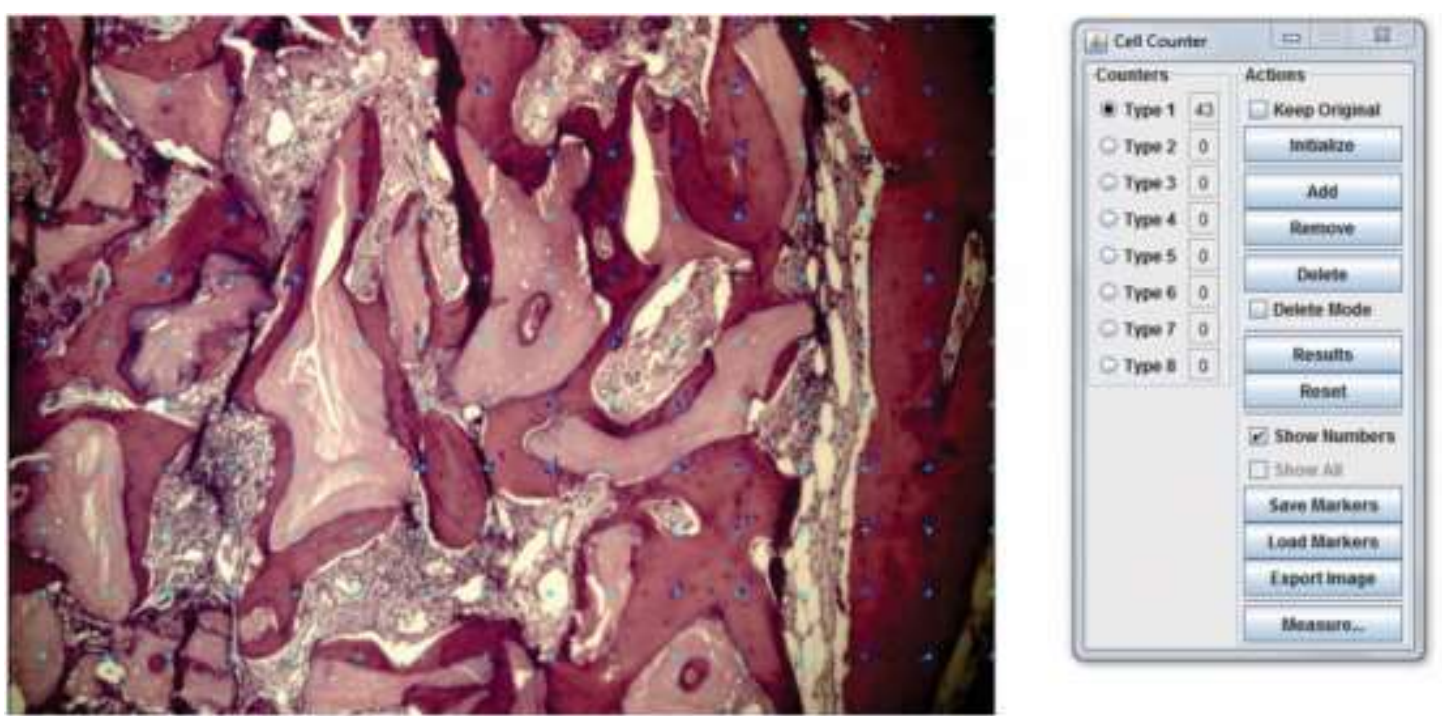

Source: Authors.

\section{Immunostaining analysis}

The immunohistochemical processing was performed at the Laboratory of Immunohistochemistry of the Basic Sciences Department of FOA - Araçatuba / UNESP.

Immunohistochemical processing was initiated by the deparaffinization steps (maintenance of the oven cuts for 20 minutes, followed by citrisolve baths and baths in decreasing concentrations of alcohols) and ending with the hydration of sections immersed in PBS (phosphate buffered saline solution 0.01M). Endogenous peroxidase activity was inhibited with hydrogen peroxide, and, in the next step, the slides underwent antigenic recovery with a phosphate citrate buffer (pH 6.0) in moist heat. Endogenous biotin was also blocked with skimmed milk for 20 minutes. As a non-specific blocking method, the primary antibody was prepared in a $1 \%$ phosphate buffer and bovine albumin solution.

For immunohistochemical processing, an antibody for osteocalcin (OC, Goatanti-OC - Santa Cruz Biotechnology, SC18319), TRAP (Goatanti-trap - Santa Cruz Biotechnology, SC30832) and VEGF (Goatanti-VEGF - Santa Cruz Biotechnology, SC1881) was used. As secondary antibodies, antibodies for biotinylated goat IgG (anti-GoatIgG-HRP, PIERCE) were used.

The detection method was performed by immunoperoxidase, and 3.3-diaminobenzidine (DAB, Sigma, St. Louis, MO, USA) was used as chromogen obtained by nuclear countercolouration with Harrics Hematoxylin. Control procedures were performed by omission of the primary antibodies (Negative control). Next, the slides passed through the dehydration steps, soaked in xylol, and the coverslips were assembled for later optical microscope analysis with a 20X magnification lens LeicaAristoplan Microsystems (Leitz, Benshein, Germany).

For each of the antibodies used, the expression of these proteins was evaluated by qualitative ordinal analysis by assigning different scores according to the number of cells and extracellular matrix area with positive immunoblotting, determined by brown staining in the cytoplasm of the cells during the process of bone remodeling. The results are presented in tables showing the representative score of the groups. The analyzer (RO) was submitted to the Kappa test where an index above 0.8 was obtained, showing that the observed scores were consistent. The distribution pattern of the immunostaining was analyzed qualitatively, assigning 0 (unmarked), 1 (weak / diffuse), 2 (moderate) and 3 (intense), in order to evaluate the expression of the 
proteins. The analysis was performed under a conventional optical microscope, and the scores were assigned by a single, previously calibrated observer.

\section{Statistical analysis}

After obtaining the histometric results, the data were statistically treated, based on the percentage values of bone neoformation, by the program Biostat 5.0 (IDSM-Amazonas / Brazil). The Shapiro-Wilk test was used to contrast the normality of the data. Once the normal distribution of data was confirmed, ANOVA variance analysis was performed, and Tukey's range test was used to verify differences between the groups. For analyses, $p<0.05$ values were considered significant.

The immunohistochemical scores for the OC, VEGF and TRAP proteins were submitted to the Shapiro-Wilk normality test, which showed heterogeneity ( $\mathrm{p}<0.05$ ) for OC and VEGF, and the non-parametric Kruskal-Wllis test was applied. Results were homogeneous ( $p>0.05$ ) for TRAP, where analysis of variance - ANOVA 1 factor was applied. Sigmaplot version 12.0 (Systat Software Inc, San Jose, California, United States of America) was used for all tests, with a significance level of 5\%.

\section{Results}

The histomorphological pattern of the stained blades was evaluated in HE, where it was possible to observe a bone neoformation process in the three groups, as shown in Figure 4. In group A, a pattern of thick bone trabeculae in a larger amount than the other groups was observed (Figure 4). Still in this group, bone fragments were seen as characterized by the absence of osteocytes in the gaps, being thus compatible with fragments of grafted bone (Figure 4A). In this group, areas of connective tissue were also observed. In the $\mathrm{AB}$ group, the same pattern of bone neoformation was observed as in the previous group; however, the trabeculae were thicker, characterizing a greater degree of maturity of the bone tissue. In group B, fine trabeculae of well-organized mature bone were observed among the granules, characterized by the presence of osteocytes, as well as areas of connective tissue (Figure 4).

Figure 4 - Bone neoformation process in the three groups hematoxylin and eosining staining in $100 \mu \mathrm{m}$ scale in optical microscope analysis with a $25 \mathrm{X}$ magnification objective. A. Group A. B. Group AB and C. Goup B.

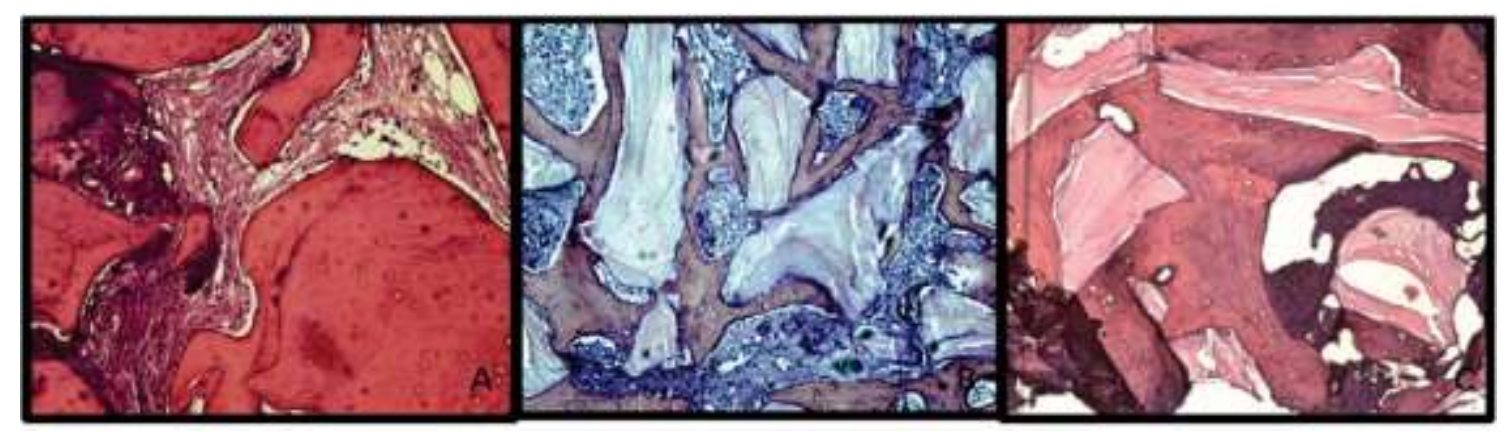

Source: Authors.

The data obtained through the histomorphometric analysis allowed to quantify the percentage of bone neoformation in each group studied (Figure 5). At least four cuts of each piece were evaluated, taking as reference the area above the interface line between the residual bone and the grafted area. 
Figure 5 - Immunohistochemical analysis with an antibody to osteocalcin. A. Group A 25 X; B. Group AB 40 X; C. Group B 25 X; MEC: extracellular matrix; OB. Osteoblast; OT. Osteocyte.

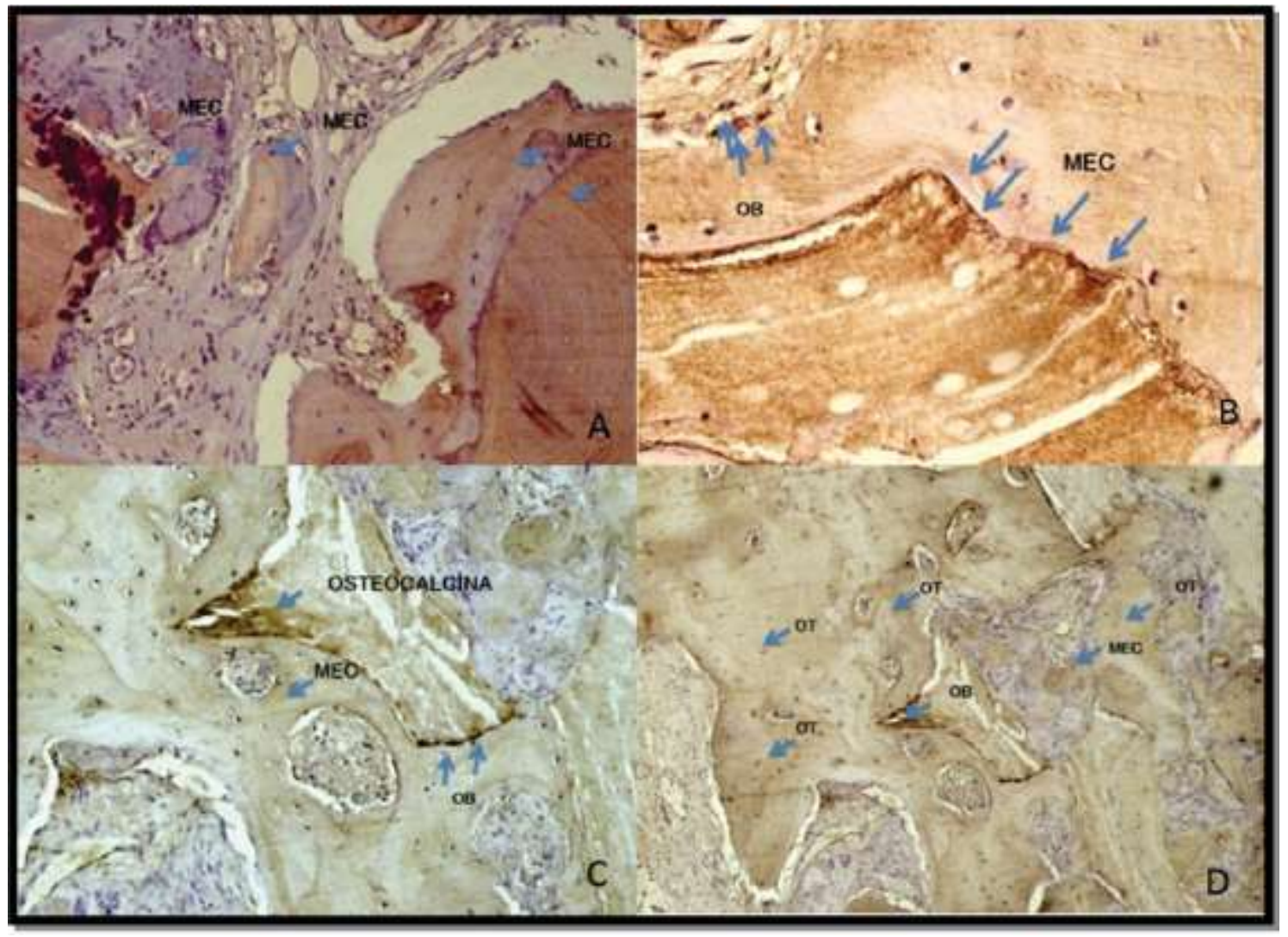

Source: Authors.

When performing the statistics of the data collected in the histometry, these pointed to statistical differences in the oneway ANOVA test $(\mathrm{p}=0.002)$. To determine the difference between groups, the Tukey's range test was applied, indicating a statistically significant difference in the comparison of group A with group B, and group A with group $A B(p=0.001$ each). Statistical data are shown in Table 3.

Table 3 - Statistical analysis results of histomorfometric data.

\begin{tabular}{|c|c|c|c|c|}
\hline Groups & $\mathbf{N}$ & Average \pm standard deviation & p(ANOVA) & p(Tukey) \\
\hline $\mathbf{A}$ & 15 & $48.96 \pm 25.6$ & \multirow{3}{*}{0,002} & $A-B A p=0-01 a b$ \\
\hline $\mathbf{A B}$ & 11 & $29.00 \pm 4.71$ & & $\mathrm{BA}-\mathrm{B}=\mathrm{ns}$ \\
\hline B & 12 & $32.26 \pm 6.02$ & & $\mathrm{~B}-\mathrm{A}=0.01 \mathrm{a}$ \\
\hline
\end{tabular}

$\mathrm{p}<0.05$

ns $=$ no significant difference

$\mathrm{a}=$ Statistically difference between groups B e A

$\mathrm{b}=$ Statistically difference between groups BA e A

Source: Authors.

The representation of the group $\mathrm{A}, \mathrm{AB}$ and $\mathrm{B}$ scores of the immunoblots of the OC, VEGF and TRAP proteins can be found in Table 4. 
Table 4 - Representative scores of imunoistochemical analysis of the three assessed groups.

\begin{tabular}{cccc}
\hline & Autogenous bone & BioOss + autogenous & BioOss \\
\hline OC & 3 & $2-3$ & 3 \\
\hline VEGF & $2-3$ & 2 & 3 \\
\hline TRAP & 2 & $2-3$ & 2
\end{tabular}

Source: Authors.

In general, immunostaining for OC was intense (3) in groups A and B, and ranged from moderate to severe (2-3) in group AB. For VEGF, immunoblotting was intense in group B, moderate in group AB, and ranged from moderate to severe in group A. For TRAP, immunolabeling was moderate in groups A and B, and ranged from moderate to severe in group AB.

Statistically speaking, no statistically significant differences were observed in the comparison between the experimental groups (A, B and AB), as well as the analyzed proteins (OC: $\mathrm{p}=0.657$; VEGF: $\mathrm{p}=0.133$; TRAP: $\mathrm{p}=0.163$ ).

Figures 5, 6 and 7 demonstrate the photomicrographs of the immunolabels of both groups, suggesting calcification, revascularization and bone resorption.

Figure 6 - Immunohistochemical analysis with an antibody to VEGF. A. Group A 40 X; B. Group AB 25 X; C. Group B 40 X; OB. Osteoblast; OT. Osteocyte.

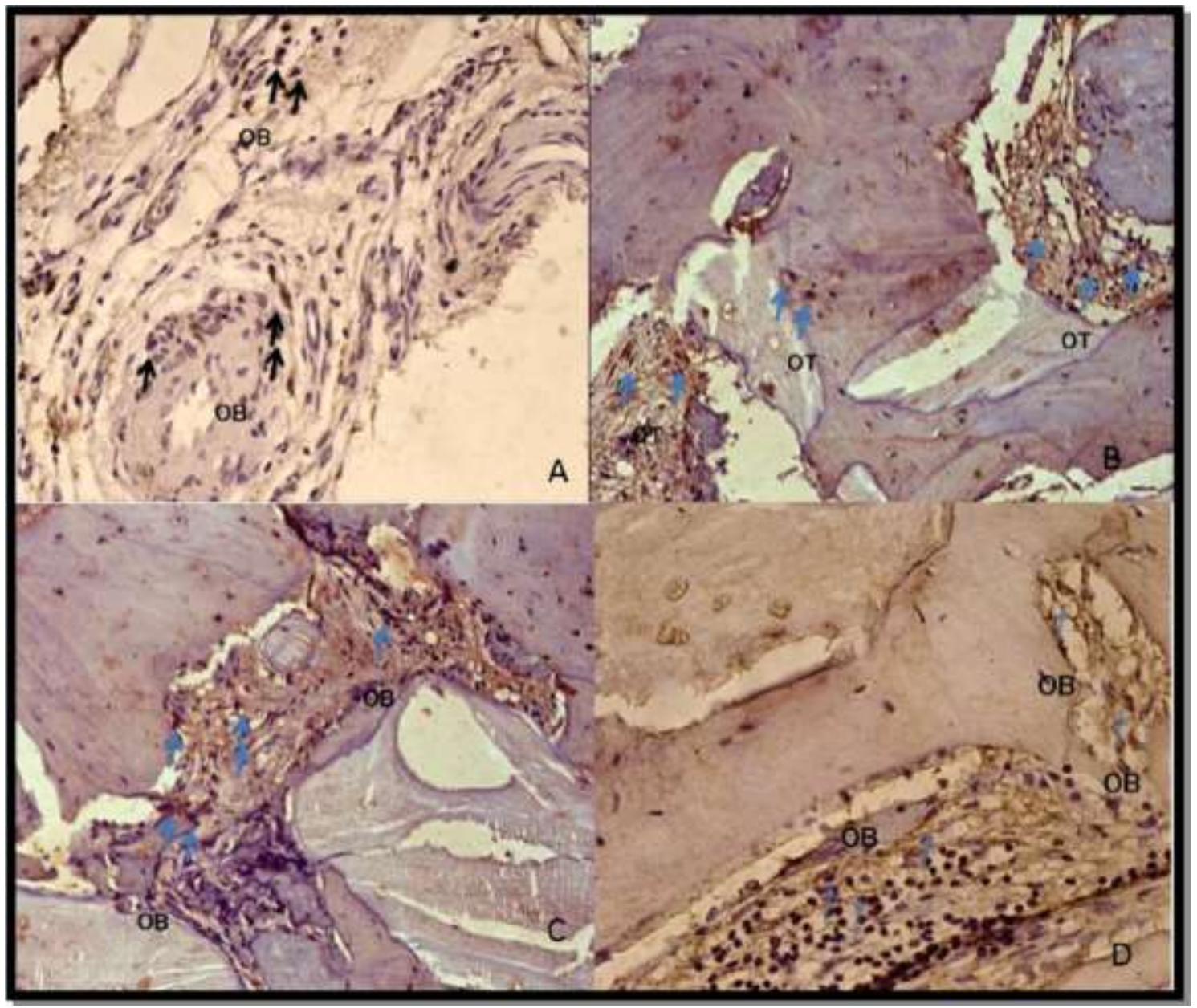

Source: Authors. 
Figure 7 - Immunohistochemical analysis with an antibody to TRAP. A. Group A 25 X; B. Group AB 25 X; C. Group B 25 X; OB. Osteoblast; OT. Osteocyte.

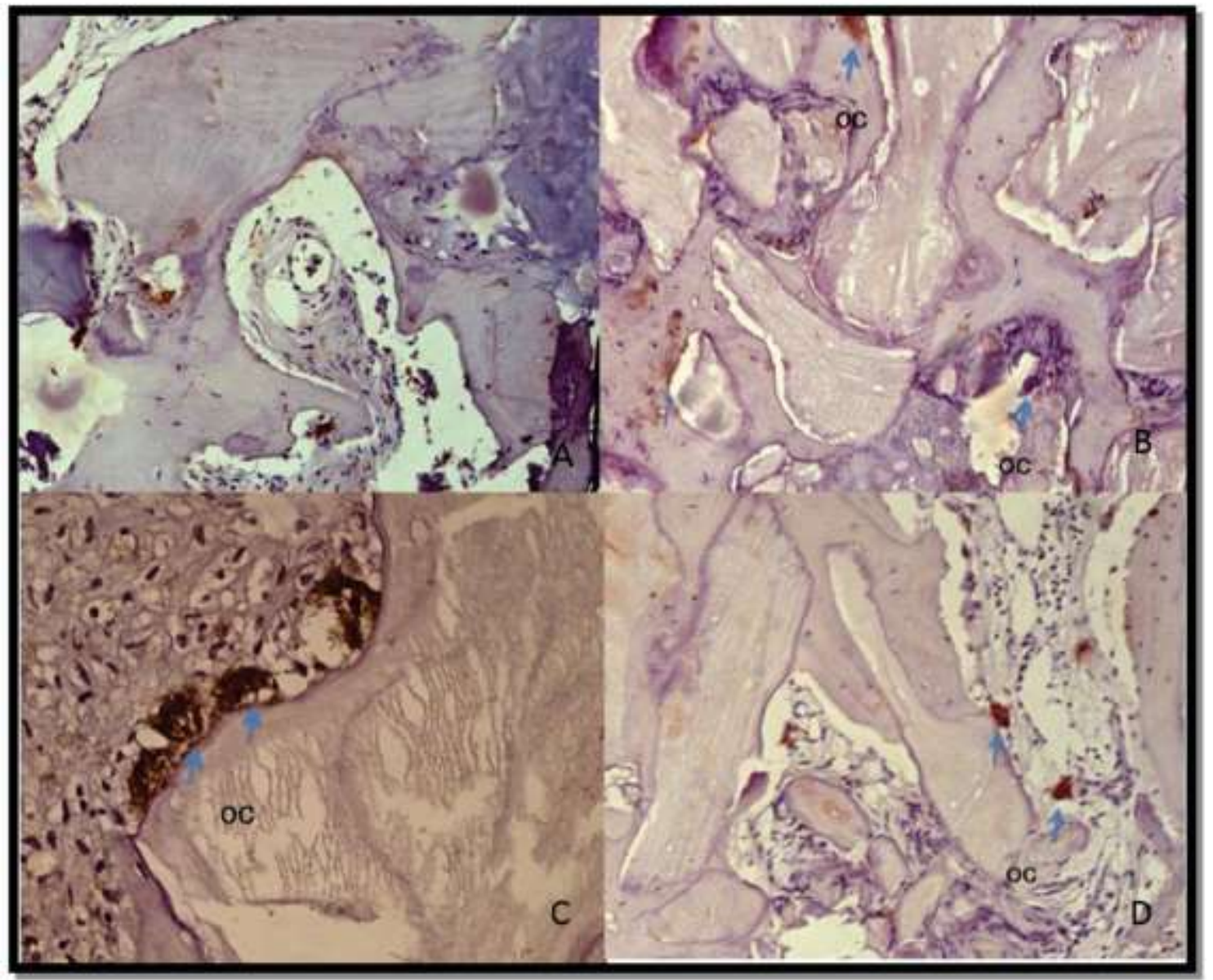

Source: Authors.

The biological interaction between the bone-biomaterial interface is essential for long-term clinical success. Bone neoformation in contact with Bio-Oss® particles has been reported in different studies (Ewers, 1999; Orsini et al. 2005; Pettinicchio et al. 2012), corroborating the findings of this study, wherein there was new bone formation around the particles, in addition to a higher percentage of bone neoformation in group B (32.26\%) when compared to group AB group (29\%), although no statistical difference was found in the comparison between these two groups.

It was observed and it is important to note that the bone neoformation immediately above the receptor / graft bed interface is higher in the 3 groups, decreasing as it approaches the Schneider membrane. The bone trabeculae in group ABwere smaller when compared to those in group B, which can be explained by the presence of autogenous bone particles that exert their osteogenic, osteoinductive and osteoconductive potential, by the transplantation of vital cells. At the same time, we believe that lower rates of bone neoformation were found in group $\mathrm{AB}$ due to the mixture with the biomaterial that does not favor the survival of the more apical cells, isolating them from the vascular nutritive bed.

In a histological analysis, as well as in immunohistochemistry, after 6 months postoperatively, it was possible to observe the presence of Bio-Oss ${ }^{\circledR}$ granules in direct contact with neoformed bone. Bio-Oss ${ }^{\circledR}$ granules are gradually reabsorbed by osteoclastose, and neoformed bone (Zaffe, 2005) is then deposited. Bio-Oss ${ }^{\circledR}$ microstructure is believed to favor the deposition of proteins that benefit bone neoformation on the surface of the biomaterial, especially some growth factors, and bone matrix proteins can infiltrate the surface layer of the biomaterial and bind to the hydroxyapatite thereof (Tapety et al., 1983). 


\section{Discussion}

One of the greatest obstacle to a proper implant and prosthetic rehabilitation is and remains the necessity of adequate bone support. The increase of the maxillary sinus floor using the lateral window technique was the method selected because it is the most commonly applied for this purpose and for having high survival rates of implants and prostheses. A recent metaanalysis of lateral approach and trans-alveolar vessels concluded that maxillary sinus elevation is a predictable treatment method demonstrating high survival rates, with few complications (Pjetursson, 2008).

Autogenous bone shows osteogenic, osteoinductive and osteoconductive properties and has, therefore, long been considered the material of choice for sinus augmentations. Because of its main disadvantages such as limited availability and donor site morbidity besides of variable resorption, various alternatives are used to substitute autogenous bone. Though bone graft materials give only few osteoinductive potential, they may act as a scaffold for bone growth. The ideal resorbable bone replacement should have biomechanical properties similar to the autogenous bone at the time of implantation, and should be remodeled in new bone (Beretta et al., 2012).

This fact corresponds to that observed in this study, since, at the end of 6 months, the presence of neoformed bone was observed along with the presence of still remaining xenograft granules. In both groups tested was possible to obtain sactisfactory results during the installation of the implants, considering the technique and the primary stability of the implants.

The osteoconductive potential of bone substitutes is regularly evaluated in humans by measuring the quality and quantity of newly formed bone in the area under investigation. Such evaluations are performed using radiography and / or a biopsy made from the grafted sinus at the end of the repair process, which in most cases extends to 6 months (Srouji et al., 2012; Zhang et al., 2012). For this reason, the sample was collected after 6 months, but this prolonged interval between treatment and evaluation of its effectiveness makes it difficult to compare the detailed and potential bone formation process of the various substitutes in question during the waiting period, the result of which was only possible to observe at the end of such period.

The autogenous bone graft, added to the biomaterial, promotes the addition of osteoinductive characteristics capable of improving the quality of the grafted bone graft (Artzi et al., 2004; Rickert et al., 2012). The use of deproteinized bovine bone in combination with the autogenous bone offers many advantages. First, it allows the volume of the graft to be increased considerably, avoiding the need to collect large amounts of autogenous bone. Second, the osteoconductive properties of bovine bone act as a framework that is essential for bone remodeling. Third, bovine bone is a calcium-deficient apatite carbonate with a crystal size of about $10 \mathrm{~nm}$, making its reabsorption considerably slower, maintaining the volume of the graft during the waiting period (Galindo-Moreno, 2007).

Complete replacement of autogenous bone by bone substitutes was evaluated in many studies. Jensen et al., 2012; Maridati et al., 2014 carried out two systematic reviews whose objective was to test the hypothesis that no difference exists in the result of treatment with implants when using Bio-Oss ${ }^{\circledR}$ pure or Bio-Oss ${ }^{\circledR}$ associated with the autogenous bone and is thus used as a graft for the increase of the floor of the maxillary sinus using the side window technique. They found that the volumetric stability of the graft improved significantly with increasing ratio of Bio-Oss®. Bone Regeneration, bone-implant contact, biomechanical values under test with the implant, and biodegradation of Bio-Oss ${ }^{\circledR}$ after a maxillary sinus lift with Bio-Oss $₫$ or Bio-Oss ${ }^{\circledR}$ mixed with autogenous bone were never compared within the same study in animals. Thus, the hypothesis that there was no difference between the use of Bio-Oss ${ }^{\circledR}$ and Bio-Oss ${ }^{\circledR}$ associated with the autogenous bone as a graft for maxillary sinus elevation could not be confirmed or rejected based on animal studies to date (Raja, 2009; Beretta et al., 2012) . In this study, it was observed that there were no significant differences in bone formation when comparing groups $\mathrm{AB}$ and $\mathrm{B}$, and it was not possible to affirm the superiority of one type of graft in relation to the other. 
Autogenous bone is confirmed as an ideal graft for bone reconstruction, as it shows the highest percentage of bone neoformation in relation to the use of Bio-Oss® or its association with it (Schmitt, 2012). This was confirmed by the ANOVA statistical test, $(\mathrm{p}=0.002)$ and Tukey's range test in the comparisons between the groups.

Osteocalcin is a non-collagenous bone matrix protein. It is synthesized by fully differentiated osteoblasts and has specific properties in bone mineralization. It is considered a known marker of viability, differentiation and osteogenic capacity in these cells. Osteocalcin is associated with bone turnover when reabsorption and formation are occurring simultaneously (Hawthorne et al., 2012) In this research, immunohistochemical markers for this protein demonstrate that in all groups studied there was intense osteocalcin activity, evidencing that even after the 6-month period, activity in relation to bone formation and mineralization persisted.

Migration and cell differentiation in the healing tissue only occur if sufficient vascularization is present. Especially in bone tissue, an intimate relationship exists between blood vessels and bone cells. VEGF is involved in angiogenesis, that is, it stimulates the proliferation of new capillaries from existing blood vessels, a common situation under repair conditions (De SouzaNunes et al., 2009). The results obtained in this research show that there is activation of the mechanism of angiogenesis and formation of osteoblasts. VEGF stimulates the formation of capillaries from those already existing in the recipient bed, and is thus extremely important in the course of bone repair.

The TRAP enzyme is secreted by the osteoclasts during the process of bone resorption. The TRAP activity was weak to moderate in the markings performed in all groups, confirming that osteoclastic activity is present in the material, but not intensely due to the maturation period of the graft. These events were probably made possible by the osteoconductive properties of the biomaterial related to its porous microstructure, as seen with autogenous bone.

\section{Conclusions}

From the results obtained in this study, it may be concluded that:

- Autogenous bone offers a higher rate of bone formation, as does its association with Bio-Oss ${ }^{\circledR}$.

- Bio-Oss ${ }^{\circledR}$ affords the expression of the osteocalcin, TRAP and VEGF proteins, resulting in osseous calcification, remodeling and revascularization.

- The use of Bio-Oss ${ }^{\circledR}$ for maxillary sinus lift through lateral window technique results in bone repair. However, reabsorption of the material was not evident. Other long-term studies are needed to determine whether Bio-Oss® can be completely resorbed.

- Predictable bone formation becomes possible when Bio-Oss $®$ is used as the osteoconductor. This finding is supported by clinical and histological evidence.

- Future studies should associate pre and post-operative control through computed tomography so that the amount and volume of bone neoformation needed in rehabilitation with implants can be more accurately measured.

\section{References}

Abrahams, J. J., \& Hayt, M. W. (2000). Original Report Sinus Lift Procedure of the Maxilla in Patients with Inadequate Bone for Dental Implants: Radiographic. AJR Am J Roentgenol, 1289-1292. http://doi.org/10.2214/ajr.174.5.1741289

Artzi, Z., Weinreb, D. M. D. M., Givol, D. M. D. N., Rohrer, D. M. D. M. D., Nemcovsky, C. E., Prasad, D. M. D. H. S., \& Tal, M. D. T. H. (2004). Biomaterial Resorption Rate and Healing Site Morphology of Inorganic Bovine Bone and beta-Tricalcium Phosphate in the Canine: A 24-month Longitudinal Histologic Study and Morphometric Analysis. The International Journal of Oral \& Maxillofacial Implants, 357-368.

Beretta M, Cicciu M, Bramanti E, Maionara C. (2012). Schneider membrane elevation in presence of sinus septa: anatomic features and surgical management. International Journal Dentistry, 1-6. http://doi.org/10.1155/2012/261905.

Bonardi, J. P., Pereira, R. S., Boos, F. B. J. D., Faverani, L. P., Griza, G. L., Okamoto, R., \& Hochuli-Vieira, E. (2017). Prospective and Randomized Evaluation of ChronOS and Bio-Oss in Human Maxillary Sinuses: Histomorphometric and Immunohistochemical Assignment forRunx2, Vascular Endothelial Growth Factor, and Osteocalcin. J Oral Maxillofac Surg, 1.e1-1.e11. https://doi.org/10.1016/j.joms.2017.09.020 
Chiapasco, M., Casentini, P., \& Zaniboni, D. (2009). Bone Augmentation Procedures in Implant Dentistry. The International Journal of Oral \& Maxillofacial Implants, 237-259.

De Souza-Nunes, L. S., De Oliveira, R. V., Holgado, L.A., Nary Filho, H., Ribeiro, D. A., \& Matsumoto, M. A. (2010). Immunoexpression of Cbfa-1 / Runx2 and VEGF in sinus lift procedures using bone substitutes in rabbits. Clin. Oral Impl. Res., 584-590. http://doi.org/10.1111/j.1600-0501.2009.01858.x

Donizeti, M., Soeiro, L., Nunes, D. S., Victor, R., Oliveira, D., Andrade, L., \& Araki, D. (2012). Bovine hydroxyapatite (Bio-Oss) induces osteocalcin, RANK$\mathrm{L}$ and osteoprotegerin expression in sinus lift of rabbits. Journal of Cranio-Maxillo-Facial Surgery, 40, 315-320. http://doi.org/10.1016/j.jcms.2012.01.014

Ewers, R. (1999). Histologic findings at augmented bone areas supplied with two different bone substitute materials combined with sinus floor lifting Report of one case. Clin. Oral Impl. Res., 96-100. http://doi.org/10.1111/j.1600-0501.2004.00987.x

Galindo-Moreno, P., Gustavo, A., Ferna, J. E., Sa, E., \& Wang, H. (2007). Evaluation of sinus floor elevation using a composite bone graft mixture. Clin. Oral Impl. Res., 376-382. http://doi.org/10.1111/j.1600-0501.2007.01337.x

Hawthorne, A. C., Salvador, L., Antunes, A. A., Antunes, A. A., \& Salata, L. A. (2012) Histological study on onlay bone graft remodeling. Part III : allografts. Clin. Oral Impl. Res., 1-9. http://doi.org/10.1111/j.1600-0501.2012.02528.x

Jensen, T., Svendsen, P. A., \& Gundersen, H. J. G. (2011). Volumetric changes of the graft after maxillary sinus floor augmen tation with Bio-Oss and autogenous bone in different ratios : a radiographic study in minipigs. Clin. Oral Impl. Res., 1-9.. http://doi.org/10.1111/j.1600-0501.2011.02245.x

Jensen, T., Schou, S., Stavropoulos, A., Terheyden, H., \& Maxillary, P. H. (2012). Maxillary sinus floor augmentation with Bio-Oss or Bio-Oss mixed with autogenous bone as graft in animals: a systematic review. International Journal of Oral \& Maxillofacial Surgery, 41(1), 114-120. http://doi.org/10.1016/j.ijom.2011.08.010

Köche, J C (2011). Fundamentos de metodologia científica : teoria da ciência e iniciação à pesquisa. (3a ed.), Editora Vozes.

Maridati P, Stofella E, Speroni S, Cicciu M, Maiorana C. (2014). Alveolar antral artery isolation during sinus lift procedure with the double window technique. Open Dentistry Journal. 8, 95-103. 10.2174/1874210601408010095

Orsini, G., Traini, T., Scarano, A., Degidi, M., Perrotti, V., \& Piccirilli, M. (2005). Maxillary Sinus Augmentation with Bio-Oss ${ }^{\circledR}$ Particles : A Light, Scanning , and Transmission Electron Microscopy Study in Man. J Biomed Mater Res B Appl Biomater, 448-457. http://doi.org/10.1002/jbm.b.30196

Pettinicchio, M., Traini, T., Murmura, G., Caputi, S., Degidi, M., Mangano, C., \& Piattelli, A. (2012). Histologic and histomorphometric results of three bone graft substitutes after sinus augmentation in humans. Clin Oral Invest, 45-53. http://doi.org/10.1007/s00784-010-0484-9

Pjetursson, B.E., Tan, W.C., Zwahlen, M., \& Langa, N.P. (2008). A systematic review of the success of sinus floor elevation and survival of implants inserted in combination with sinus floor elevation Part I : Lateral approach. J Clin Periodontol, 35, 216-240. http://doi.org/10.1111/j.1600-051X.2008.01272.x

Raja, S. V. (2009). Management of the Posterior Maxilla with Sinus Lift : Review of Techniques. International Journal of Oral \& Maxillofacial Surgery, 67(8), 1730-1734. http://doi.org/10.1016/j.joms.2009.03.042

Rancitelli D, Borgonovo AE, Cicciu M, Re D, Rizza F, Frigo AC, Maiorana C. (2015) Maxillary Sinus Septa and Anatomic Correlation With the Schneiderian Membrane. Journal of Craniofacial Surgery. 26(4), 1394-1398. 10.1097/SCS.0000000000001725

Rickert, D., Slater, J. J. R. H., Meijer, H. J. A., \& Vissink, A. (2012). Maxillary sinus lift with solely autogenous bone compared to a combination of autogenous bone and growth factors or (solely) bone substitutes. A systematic review. Int J Oral Maxillofac Surg, 160-167. http://doi.org/10.1016/j.ijom.2011.10.001

Schmitt, C. M., Schmitt, C. M., Doering, H., Schmidt, T., Lutz, R., Wilhelm, F., \& Schmitt, C. M. (2012). Histological results after maxillary sinus augmentation with Straumann @ trolled clinical trial. Clin Oral Implants Res, 1-10. http://doi.org/10.1111/j.1600-0501.2012.02431.x

Schweikert, M., Lang, N. P., \& Botticelli, D. (2011). Use of a titanium device in lateral sinus floor elevation : an experimental study in monkeys. Clin Oral Implants Res, 100-105. http://doi.org/10.1111/j.1600-0501.2011.02200.x

Srouji, S., Ben-David, D., Funari, A., Riminucci, M., \& Bianco, P. (2012). Evaluation of the osteoconductive potential of bone substitutes embedded with schneiderian membrane or maxillary bone marrow-derived osteoprogenitor cells. Clinical Oral Implant Research. 1-7. http://doi.org/10.1111/j.16000501.2012.02571.x

Stacchi C, Lombardi T, Cusimano P, Berton F, Lauritano F, Cervino G, Lenarda R, Cicciu M. (2017). Bone Scrapers Versus Piezoelectric Surgery in the Lateral Antrostomy for Sinus Floor Elevation. Journal of Craniofacial Surgery, 28(5), 1191-1196. 10.1097/SCS.0000000000003636.

Stern, A., \& Green, J. (2012). Sinus Lift Procedures: An Overview of Current Techniques. Dent Clin North Am, 56, 219-233. http://doi.org/10.1016/j.cden.2011.09.003

Tapety, F.I., Amizuka, N., Uoshima, K., Nomura, S. \& Maeda A. (1983). A histological evaluation of the involvement of Bio-Oss in osteoblastic differentiation and matrix synthesis. Clin Oral Implants Res, 315-324. http://doi.org/10.1111/j.1600-0501.2004.01012.x

Tatum, H. (1986). Maxillary and sinus implant reconstructions. Dent Clin North Am, 30, 207-229.

Zaffe, D. (2005). Histological study on sinus lift grafting by Fisiograft and Bio-Oss. J Mater Sci Mater Med, 16, 789-793. http://doi.org/10.1007/s10856-0053574-5

Zhang, Z., Egaña, J. T., Reckhenrich, A. K., Schenck, T. L., Lohmeyer, J. A., Schantz, J. T., \& Schilling, A. F. (2012). Cell-based resorption assays for bone graft substitutes. Acta Biomaterialia, 8, 13-19. http://doi.org/10.1016/j.actbio.2011.09.020 